\title{
EFFECT OF POLLINATION ON RAPESEED (BRASSICA CAMPESTRIS L. VAR. TORIA) PRODUCTION IN CHITWAN, NEPAL
}

\author{
R. Pudasaini ${ }^{1}$ and R. B. Thapa ${ }^{2}$
}

\begin{abstract}
Rapeseed is an important cash crop of Nepal and an experiment was conducted to study the effect of pollination on its production in Chitwan during 2012-2013. The experiment was designed in Randomized Complete Block with four replications and five pollination treatments. The rapeseed plots were caged with mosquito nets at $10 \%$ flowering except natural pollination. Two-framed colonies of Apis mellifera L. and Apis cerana $F$. were introduced separately for pollination, and control plot caged without pollinators. Seed set increased by $48.72 \%$ with Apis cerana $F$. and $45.73 \%$ with Apis mellifera L. pollination as compared to the control. The highest seed yield was obtained from Apis cerana $F$. (1.11 $\mathrm{mt} / \mathrm{ha})$, followed by Apis mellifera L. (0.88 $\mathrm{mt} / \mathrm{ha})$, hand $(0.75 \mathrm{mt} / \mathrm{ha})$, natural pollination (0.66 mt/ha) and control $(0.13 \mathrm{mt} / \mathrm{ha})$, respectively. This study clearly indicated pollination deficit under natural condition, and therefore, management of honeybee is necessary for higher production and productivity of rapeseed under Chitwan condition.
\end{abstract}

Key words: Apis cerana, Apis mellifera, rapeseed pollination, seed yield

\section{INTRODUCTION}

Oilseed is one of the important cash crops of Nepal, which occupied 213706 ha area, with production of $176186 \mathrm{mt}$ and productivity of $0.82 \mathrm{mt} / \mathrm{ha}$ in 2010/2011, where as in 2011/2012, area increased to 214835 ha, with production of 179145 $\mathrm{mt}$ and productivity of $0.83 \mathrm{mt} / \mathrm{ha}$ (MoAC, 2011/2012). Other oilseed crops grown in the country are soybean, sunflower, sesame, groundnut, castor, linseed, and niger. Rapeseed (Brassica campestris L. var. toria) alone occupies about $85 \%$ of the total oilseed area in the country and it is a dominant winter season oilseed crop (Basnet, 2005). It is mostly grown after monsoon maize in upland and after early rice in lowland of Terai, inner Terai and mid-hills (Ghimire et al., 2000).

This crop is important from income generation point of view and is prominent sources of fats, protein and vitamins as compared to cereals and legumes in Nepalese diet (Chaudhary, 2001). Its seeds contain $40-45 \%$ oil and $20-25 \%$ protein (Hasanuzzaman et al., 2008). Similarly, 4.8\% nitrogen, 2\% phosphorus and 1.3\% potash can be obtained from mustard oil cake (Prasai and Yadhav, 1999).

Rapeseed is a cross-pollinated crop. It requires sufficient pollinating agents for better pollination and seed production. The flowers of rapeseed are very attractive to bees. Honeybees visit rapeseed flowers for collection of both pollen and nectar, which in turn results into florets cross-pollination. Honeybees are naturally important pollinators of plants throughout their natural range. The main

\footnotetext{
${ }^{1}$ Student (M.Sc.Ag. Entomology) rameshwor.ent@gmail.com

${ }^{2}$ Professor (Entomology), Institute of Agriculture and Animal Science, Rampur, Chitwan, Nepal.
} 
significance of honeybees and beekeeping is pollination, whereas the hive products (honey, wax etc.) are of secondary value (Verma, 1990).

Scientific evidence confirms that bee pollination improves the yield and quality of crops, such as fruits, vegetable seeds, spices, oilseeds and forage crops (Partap and Partap, 1997; Thapa, 2006). For better pollination and productivity of crops, the proper methods of utilizing pollinators are important, which are specific for honeybees, other bees and other insects (Sihag, 2000). Hence, this study was conducted to see the effect of pollination on yield of rapeseed.

\section{MATERIALS AND METHODS}

An experiment was conducted at Jutpani VDC, Chitwan district of Nepal during October 2012 to February 2013. The experiment was laid out in Randomized Complete Block Design (RCBD) with four replications and five treatments namely: i) Pollination by Apis mellifera L.; ii) Pollination by Apis cerana F.; iii) Hand pollination; iv) Natural pollination; and v) Control (no pollination). The plot size of each treatment was $3 \mathrm{~m} \times 5 \mathrm{~m}\left(15 \mathrm{~m}^{2}\right)$ separated by $0.5 \mathrm{~m}$ distance between plots and $1 \mathrm{~m}$ between replications. Rapeseed variety Pragati was sown on 03 November 2012 with all the agronomical practices followed as per recommendation (Singh et al., 2010; Basnet, 2005). The fertilizers were applied @ 15 ton/ha FYM, 60:60:40 $\mathrm{kg} \mathrm{NPK} / \mathrm{ha}$ and Sulphur $30 \mathrm{~kg} / \mathrm{ha}$. Full dose of FYM, half nitrogen, full phosphorus and potassium were applied as a basal dose and remaining nitrogen as top dressing at 21 days after sowing (DAS). The seeds were sown at 3-4 cm depth of soil @ $6 \mathrm{~kg}$ / ha in well prepared field maintaining $20 \mathrm{~cm} \times 5 \mathrm{~cm}$ spacing between row to row and plant to plant, respectively. Two intercultural operations were done to remove weeds during early vegetative growth period at 21 DAS and 35 DAS.

Native honeybee, Apis cerana F. exotic honeybee, Apis mellifera L., control and hand pollination treatments were covered with mosquito nets $(5 \mathrm{~m} \times 3 \mathrm{~m} \times 2.5 \mathrm{~m}$ size $)$. The caged were erected on field plots when the crop reached at $5-10 \%$ flowering stage at 28 DAS. Thereafter, already produced four colonies of Apis cerana $\mathrm{F}$. and four colonies of Apis mellifera L. with fully covered two- frame hives with a queen, and containing broods and eggs of each species were placed separately inside cage at 29 DAS on experiment field. Bee colonies were fed with 1:1 sugar syrup twice a week throughout the pollination period. For hand pollination, twenty plants were randomly selected in each replication within $\mathrm{m}^{2}$ area. Then pollens were collected from border plants with the help of fine camel brush and pollinated between 8:00 am-10:00 am and covered by caging with mosquito net. These honeybee colonies and mosquito cages were removed at 65 days after sowing (DAS) from bee pollinated plots and at 100 DAS from no insect pollinated plots, respectively. Twenty randomly selected plants were taken from each experimental plot ( except in hand pollinated plots where all hand pollinated plants used) for data recording, like plant height, branch number, pod number and length, seed number and yield etc. Thus recorded data were subjected to analysis of variance (ANOVA) and significant mean differences were separated by Duncan's Multiple Range Test (DMRT) at 0.05 percent level of significance (Gomez and Gomez, 1984). 


\section{RESULTS AND DISCUSSION}

As presented on Table 1, the highest plant height was measured on control plots (no insect pollinated), i.e. control plots $(103 \mathrm{~cm})$ and the lowest in Apis cerana F. pollinated plants $(81.86 \mathrm{~cm})$. Similarly, the highest branch numbers were observed on no insect pollinated plants, i.e. control plants (3.273 branches per plant) and the lowest on Apis cerana F. pollinated plants (2.158 branches per plant).

Native honeybee, $A$. cerana $\mathrm{F}$. pollinated plants resulted the highest pod length $(6.01 \mathrm{~cm})$ followed by Apis mellifera L. $(5.86 \mathrm{~cm})$ and the lowest on no insect pollinated plants, i.e. control $(3.33 \mathrm{~cm})$ (Table 2). The longest pod size of Apis cerana $\mathrm{F}$. pollinated plants and the shortest pod size on control plants has also been reported (NARC, 2008).

Similarly, the highest number of seeds per pod was recorded in Apis cerana $\mathrm{F}$. pollinated plants (14.14 seeds per pod) and the lowest number of seeds on no insect pollinated plants (7.25 seed per pod) (Table 3$)$. Similar result was reported by Partap and Verma (2010) that showed 42\% higher formation per pod of radish with Apis cerana $\mathrm{F}$. bees than open pollinated plants.

Table 1.Variations on plant height and branch number of rapeseed due to different pollination treatments in Jutpani VDC, Chitwan, 2012/13*

\begin{tabular}{lcc}
\hline Treatments & Plant height $(\mathrm{cm})$ & Branch (No/plant) \\
\hline Apis cerana pollination & $81.86 \mathrm{~d}$ & $2.158 \mathrm{c}$ \\
Apis mellifera pollination & $83.43 \mathrm{~cd}$ & $2.287 \mathrm{bc}$ \\
Hand pollination & $85.04 \mathrm{c}$ & $2.487 \mathrm{bc}$ \\
Open pollination & $88.06 \mathrm{~b}$ & $2.537 \mathrm{~b}$ \\
Control (No pollination) & $103.0 \mathrm{a}$ & $3.273 \mathrm{a}$ \\
\hline
\end{tabular}

* Means followed by the same letter in each column are not

significantly different by DMRT at $\leq 0.05$ percent level

Table 2.Variations on pod length and pod number of rapeseed due to different pollination treatments in Jutpani VDC, Chitwan, 2012/13*

\begin{tabular}{lcc}
\hline Treatments & Pod length $(\mathrm{cm})$ & Pod (No/plant) \\
\hline Apis cerana pollination & $6.01 \mathrm{a}$ & $93.15 \mathrm{a}$ \\
Apis mellifera pollination & $5.86 \mathrm{a}$ & $89.24 \mathrm{a}$ \\
Hand pollination & $4.55 \mathrm{~b}$ & $69.59 \mathrm{~b}$ \\
Natural pollination & $4.33 \mathrm{~b}$ & $64.96 \mathrm{~b}$ \\
Control (No pollination) & $3.33 \mathrm{C}$ & $45.72 \mathrm{C}$
\end{tabular}

${ }^{*}$ Means followed by the same letter in each column are not significantly different by DMRT at $\leq 0.05$ percent level

Similarly, Apis cerana F. pollination resulted the highest number of pods ( 93.15 pods per plant) followed by Apis mellifera L. Pollination (89.24 pods per plant), and again the lowest on no insect pollinated plants (45.72 pods per plant), which is similar to the result of Munawar et al. (2009) that number of pods per plants 
was higher than without pollination. The highest numbers of pods/ plant on pollinated plants than on control has also been reported by NARC (2008).

Table 3.Variations on seed yield and harvest index of rapeseed due to different pollination treatments in Jutpani VDC, Chitwan, 2012/13*

\begin{tabular}{lccc}
\hline Treatments & Seed $($ No/pod) & Seed yield $(\mathrm{mt} / \mathrm{ha})$ & Harvest Index $(\mathrm{HI})$ \\
\hline Apis cerana pollination & $14.14 \mathrm{a}$ & $1.11 \mathrm{a}$ & $0.61 \mathrm{a}$ \\
Apis mellifera pollination & $13.36 \mathrm{a}$ & $0.88 \mathrm{~b}$ & $0.50 \mathrm{~b}$ \\
Hand pollination & $11.43 \mathrm{~b}$ & $0.75 \mathrm{bc}$ & $0.48 \mathrm{~b}$ \\
Natural pollination & $10.89 \mathrm{~b}$ & $0.66 \mathrm{c}$ & $0.44 \mathrm{~b}$ \\
Control (No pollination) & $7.25 \mathrm{c}$ & $0.13 \mathrm{~d}$ & $0.11 \mathrm{c}$
\end{tabular}

* Means followed by the same letter in each column are not significantly different by DMRT at $\leq 0.05$ percent level

Figure 1. clearly shows that the highest seed yield was obtained from plants pollinated by Apis cerana $\mathrm{F}$. (1.11 mt/ha), followed by Apis mellifera L. pollinated plants $(0.879 \mathrm{mt} / \mathrm{ha})$, hand pollinated plants $(0.752 \mathrm{mt} / \mathrm{ha})$, open pollinated plants $(0.6603 \mathrm{mt} / \mathrm{ha})$ as compared to control, i.e. no insect pollinated plants (0.1278 mt/ha). Similar results have been reported by Munawar et al. (2009). The yield of mustard by bee pollination was $7.6 \mathrm{gm} / \mathrm{plot}$ and without pollination 1.51 $\mathrm{gm} / \mathrm{plot}$, respectively. Similarly, radish plants caged with an Apis cerana F. colony yielded $45 \%$ higher seed weight than open pollinated plants and plants with insect visitors excluded had no pod set at all (Partap and Verma, 2010).

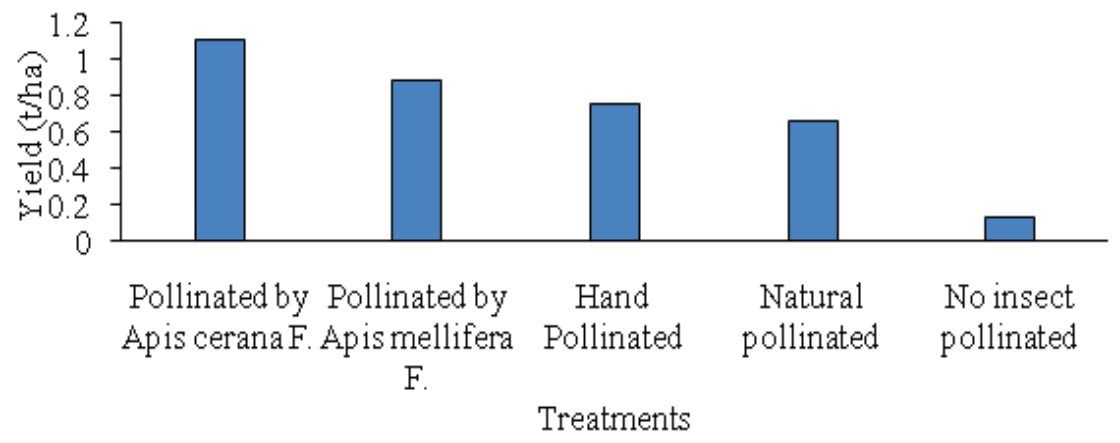

Figure 1. Yield of rapeseed with different treatment in Jutpani VDC, Chitwan, 2012/013

\section{CONCLUSIONS}

Plants not pollinated by bees resulted in taller plants height, higher branch numbers and lower yield. Pollination by bees reduced flowers longevity and improved pod length, seeds number per pod, pod number per plants, and test weight in rapeseed. Among the honeybees, Apis cerana F. was the most efficient pollinators that produced higher quality and quantity of rapeseed seeds than Apis mellifera L. Hence, the study clearly indicated that there is deficit of pollinators and honeybees like Apis cerana $\mathrm{F}$. and Apis mellifera L., being efficient pollinators 
of mustard their conservation and management is necessary for higher quality and quantity of rapeseed production and productivity under Chitwan condition of Nepal.

\section{REFERENCES}

Basnet, K. B. 2005. Effect of different combinations of nutrient sources and weeding practice on the physiological characters of rapeseed in humid subtropical condition of Chitwan. Journal Institute of Agriculture and Animal Science 26: 51-55.

Chaudhary, B. P. 2001. Effect of crop geometry, nitrogen and weed management on mustard (Brassica juncea). M.Sc. Ag. Thesis, Rajendra Agricultural University, Bihar, Pusa, India.

Ghimire, T. B., Chaudhary R. N., and Ray. S. P., 2000. Quantification of yield limiting constraints in toria production. Annual Report, 2000/2001. National Oil Research Program. $61 \mathrm{p}$.

Gomez, K. A. and A. A. Gomez., 1984. Statistical procedures for agriculture research. John Wiley and Sons, New York, USA.

Hasanuzzaman, M., Karim, M. F. and Ullah, M. J., 2008. Growth dynamic of rapeseed (Brassica campestris L.) cv. SAU Sarisha-1 as influenced by irrigation levels and row spacing. Australian Journal of Basic and Applied Sciences 2(4): 794-799.

MoAC, 2011/2012. Statistical information on Nepalese agriculture. Government of Nepal, Ministry of Agriculture and Co-operatives, Agri-Business Promotion and Statistics Division, Singha Durbar, Kathmandu. Nepal.

Munawar, S. M., Raja, S., Siddique, M., Niaz S., and Amjad, M., 2009. The pollination by honeybee (Apis mellifera L.) increases yield of canola (Brassica napus L.). Pakistan Entomology Journal 31(2):103-106.

NARC, 2008. Introduction of trained bees, Apis mellifera L. for quality seed and higher seed on mustard, Brassica campestris Var. toria in Nepalese condition. Annual Technical Report 2006-2007. Entomology Division, Nepal Agriculture Research Council. Khumaltar, Lalitpur, Nepal. pp. 27-32.

Partap, U. and Partap, T., 1997. Managed crop pollination. The missing dimension of mountain crop productivity. Discussion Paper Series No. MFS 97/1, ICIMOD, Kathmandu, Nepal.

Partap, U. and Verma, L. R., 2010. Pollination of radish by Apis cerana F. Journal of Apicultural Research 33 (4):237-24.

Prasai, H. K. and Yadhav, H. N., 1999. Performance evaluation of mustard at Banigama, Morang, Annual Report, Regional Agriculture Region Station, Tarahara, Nepal. pp. 141-143.

Sihag, R. C. 2000. Management of bees for pollination. In: M. Matska, L. R. Verma, S. Wongsiri, K. K. Shrestha and U. Partap (eds.) Asian Bees and Beekeeping-Progress of Research and Development. Proceedings of Fourth Asian Apicultural Association International Conference, Kathmandu. March 23-28, 1998. Oxford and IBH Publishing Company, Private Limited, New Delhi, India.

Singh, C., Singh, P. and Singh, R., 2010. Modern techniques of raising field crops. $3^{\text {rd }}$ edition. Oxford and IBH Publishing Company, Private Limited, New Delhi, India.

Thapa, R. B. 2006. Honeybee and other insect pollinators of cultivated plants: A review. J. Inst. Agric. Anim. Sci. 27:1-23.

Verma, L. R. 1990. Beekeeping in integrated mountain development: Economic and scientific perspectives. ICIMOD senior fellowship Series, No. 4 Oxford and IBH Publishing Company. Private. Limited, New Delhi, India. 